\section{Alexandra Dugushina}

Peter the Great Museum of Anthropology

and Ethnography ("Kunstkamera"), Russian Academy of Sciences, St.Petersburg dugushina@kunstkamera.ru

ORCID: 0000-0003-2681-8700
Data przesłania tekstu do redakcji:08.10.2019

Data przyjęcia tekstu do druku: 03.04.2019

\title{
Birth Rituals and Cultural Memory of Albanian Diaspora in Ukraine
}

Abstract: Dugushina Alexandra, Birth Rituals and Cultural Memory of Albanian Diaspora in Ukraine. "Poznańskie Studia Slawistyczne" 16. Poznań 2019. Publishing House of the Poznań Society for the Advancement of the Arts and Sciences, Adam Mickiewicz University, pp. 89-100. ISSN 2084-3011.

The article is devoted to the traditional birth rituals of Albanians of Ukraine reflected in their cultural memory. Several migrations from the South Albania since XV-XVI century, following by different geographic, political, ethnic and sociocultural surroundings influenced a lot Albanian traditional culture but ritual practices related to the human birth, still take a special place in the cultural memory of the Albanian diaspora. Memory on ritual practices related to the birth is mostly based on contrasting the past and present that illustrated by rituals related to the folk obstetrics and beliefs about protection, health and well-being of a mother and a child. Specificity of birth rituals is interpreted by bearers of tradition as representation of the group's identity in a multiethnic environment in the South Ukraine and as a way for Albanians to save and transmit their culture.

KEYwORDS: Albanians of Ukraine; birth rituals; cultural memory; traditional culture

\section{Introduction: traditional culture and cultural memory}

Being in transformation of economic, social, spatial or temporal circumstances, traditional culture of ethnic groups undergoing changes is the undoubted subject of cultural memory. Since the concept of cultural memory based on the ideas of M. Halbwachs and J. Assmann could be interpreted as "the interplay of present and past in socio-cultural context" (Erll, 2008, 1-2; 2011), different forms of cultural knowledge as rituals, language, images and experiences, etc., symbolically encoded in culture, are a focus of cultural memory studies. The cultural memory as a way of 
transmission of cultural meanings through generations is essential for a social group because of a sense of identity and currently controlling the experiences, actions and life practices of people: the past turns to symbolic figures created by the group's memory (Assmann, 2004, 54).

The traditional birth rituals of Albanian diaspora in the South Ukraine are the subject of cultural memories for diaspora's representatives. Since $\mathrm{XV}-\mathrm{XVI}$ centuries, drifting through the times of several migrations from the South Albania, the culture of Albanians, that now live in Ukraine, was transformed under the different geographic, political, ethnic and sociocultural conditions having obtained innovations and, inevitably, the loss of its specific elements. Compared with funeral or wedding rituals as other parts of traditional life cycle, birth rituals are the most mobile layer of traditional culture subjected to external transformation. The continuing development of medical assistance regulating the obstetric aid and childcare is the well-known reason for the gradual disappearance of folk obstetrics, that means the rituals accompanying childbirth like sacral actions with the placenta and the umbilical cord or the first sacral bathing baby performed by a midwife are no more relevant. Nevertheless, despite the modern qualified medical care, the ritual actions related to the birth, protection, health and well-being of a mother and a child still take a special place in the cultural memory of the Albanian diaspora in Ukraine. This fact could be explained by the vital and culturally relevant functions of the birth rituals: the acceptance of a new person into the ethnosocial community for its safe reproduction and development. The customs identified with the birth of children continue to live in the ethnos' memory as folk mythology, images and rituals determining at the present time the diaspora's values. For this reason, the concept of cultural memory in relation to the traditional birth rituals seems to be the most adequate approach to studying this aspect of culture from the nowadays perspective. Memory on ritual practices related to the birth is a way for Albanians to save and transmit their culture. As well as the specificity of birth rituals is directly related to the representation of the group's identity in the multiethnic environment in the South Ukraine. 


\section{Short historic background on Albanians of Ukraine}

Southern borders of Ukraine are an area of close neighborhood of multiple ethnic groups: Ukrainians, Russians, Bulgarians, Gagauzians, Albanians, Greeks, Moldavians, etc. (Ivanova, Chizhikova, 1979). In particular, the territory of the Northern Black Sea region (the Budzhak region) and the Azov Sea region are places of compact settlement of the Balkan colonists - Bulgarians, Gagauzians and Albanians. The history of Albanian migration went back to the XV-XVI centuries and closely related to the Ottoman conquest of the Balkan lands influenced the massive migrations in different directions (Arsh, 1992, 134; Ivanova, 2006, 81, 301). Saving from the Turkish oppression, the South-East Albanian population to which, obviously, belonged the ancestors of the Albanians in the Ukraine, ${ }^{1}$ moved to the eastern part of Bulgaria in the end of XV-the begining of XVI centuries, where they founded numerous villages. ${ }^{2}$ The next move took place in $1809-1810$ when Albanians migrated to the territory of Russian Empire (South Bessarabia) together with the population flow of Bulgarians and Gagauzians (Derzhavin, 1948, 156-169). The resettlement of these ethnic groups is related to the Russian policy aimed to populate the deserted steppe territories receded to Russia after the Russian-Turkish wars. The orthodox Balkan population was offered a land and some profitable conditions for farming. So the first village Karakurt (former name - Zhovtnevoye) was established in 1811 near the Bolgrad district of Odessa with the mixed Albanian, Bulgarian and Gagauzian population. In 1861-1862 a part of Albanian population moved to the Melitopol region (now - Zaporozhye region of Ukraine) and founded three other villages existing till nowadays: Albanian-speaking Georgievka (formerly known as Tyushki) and Devninskoye (before - Taz), and AlbanianGagauzian-speaking village Gammovka (former name - Dzhandran). ${ }^{3}$

${ }^{1}$ Comparing with the dialect landscape of Albania as well as relying on accessible historical and ethnographic data, the dialect of Albanians of the Ukraine is considered to belong to the southeastern Albanian dialect group, embracing the modern regions of Korça and Vithkuq, Devoll and Kolonja (Desnitskaya, 1968, 475; Sharapova, 1990, 114-118).

${ }^{2}$ For now there is an only one Albanian-speaking village in the southeast of Bulgaria - Mandritsa, where people speak language close to the dialect of Albanians of the Ukraine (Morozova, 2012).

${ }^{3}$ More detailed historical research is presented in (Novik et al., 2016). 
Nowdays Albanians living in the polyethnic regions of Budzhak and Azov in Ukraine represent a unique ethnic community that has been developing for five centuries outside its homeland. On the one hand, long living in isolation from the original tradition led to the preservation of archaic cultural elements as, for example, the surviving of dialect dating back to the medieval state of Albanian language. On the other hand, the sustainable contact situation with dominant ethnic groups (as Bulgarians and Russians) resulted in cultural interaction reflected on multiple innovative features. Due to the passage of time some cultural and linguistic borrowings were organically adapted by Albanian culture and now perceived as their own.

The paper is based on the field data from the Albanian villages in Ukraine, collected in six expeditions from 2008 to 2013 within the work of linguistic and ethnographic project ruled by St. Petersburg State University and Peter the Great Museum of Anthropology and Ethnography "Kunstkamera" Russian Academy of Sciences (Novik et al., 2016). Since the residents of Albanian villages in Ukraine speak Albanian, Bulgarian, Gagauzian and Russian, the field data was collected in different languages but in this paper all citations from people's narratives are translated in English. Working on the topic about birth rituals there was a goal to reconstruct all accessible ritual traditional cycle because of lack of any detailed ethnographic description related to it. Balancing on questions "what do you do now" and "how did you do before" it was clear that a part of traditional ritualism on childbirth became history but cultural memory makes it possible to keep it alive.

\section{Cultural memory and birth rituals: contrasting "today" and "before"}

Cultural memory is always shared by its special bearers. It stands to reason that bearers and mediators of knowledge related to childbirth are women, and mostly those who were born in 1930's - the beginning of 1940 's, when customs related to domestic midwifery were fully respected. The women's narratives about formerly existed birth rituals actualize the knowledge of the older generation - their mothers, mothers-in-law and grandmothers, whose experience is regarded as authentic and sacred: "All that I know was told by my mother-in-law, everything because of her," 
"before-before my mother-in-law told me," "that our mothers did" (recorded in 2010, village Georgievka, Ukraine).

Imagining of non-modernity and possibility to live at the same time in two temporal hypostases are universal attributes of cultural memory (Assman, 2004, 60). Memories based on a contrast between present and past characterize the feelings of the older generation reflecting on the situation when young people don't respect so much traditional culture. A typical discursive strategy of female informants is expressed by the confidence about "how it should be" that opposed to the controversial examples: "but now...", "but now what we have?...": "It's a routine, earlier-earlier, but now - nothing. Very-very good, and very somehow nice in the soul, when doing this, that old people used to do before. But now ..." (A.I. Kanarova, born in 1939, Albanian, recorded in 2010, village Georgievka, Ukraine).

But, as it can be supposed, not every ritual practice related to the childbirth tends to be in contrast with modern situation and interpreted by Albanian women as a lost of traditional culture. For example, some medical difficulties with domiciliary obstetrics or some everyday challenges concerning childcare like absence of good clothing for newborns and diapers are way beyond the women's reflection. Some aspects of traditional culture are not recognized by people as really "old" while the archaic lexicon related to the birth rituals gives data on Albanian tradition four-five centuries ago. For example, the names of collective ritual visits to a mother and a child shed light on the ethnocultural areas of contacts of Albanian diaspora. The name kadesh is used for ritual celebration on $9^{\text {th }}$ day after the baby's birth and corresponds to the dialect Bulgarian nomination кадеш "smoke", spread in the northeastern part of Bulgaria (the Dobrudzha region) - the area of long-standing settlement of the ancestors of Albanians of Ukraine after the leaving their motherland (BDA 1966, map 215 «названия за дим»; Plotnikova, 2004, 158). Another ceremony on $40^{\text {th }}$ after child birth is called poganik which is an absolutely archaic term traced till now in South Albania - the area of origin of Albanians of Ukraine. Corresponding with two main meanings - "birthday ceremony" and "ritual birth bread" (KD [QSA], poganik; KD [QSA], boganik) - the term and ritual poganik is an example of valuable cultural artifact living constantly in the ethnic cultural memory.

In this article we will focus mostly on selective aspects of birth practices that have a special reflection in people's memories about their culture 
in the past. Such reflection could be seen mostly in taboos and instructions regarding the pregnancy and the period after childbirth, in other words, in practices regulating the position of a mother and a baby in family and society, their safe wellbeing, socialization and growth. For now the people's narratives about rituals before and after the birth are very emotional because they are full of critical deficiency of the old tradition and memory on it. For example: "Nobody had compassion to the pregnant like now. The more you work, the more you walk, the easier you give birth. That what remained from our parents, from our ancestors" (A.K. Burlachko, born in 1940, Albanian, recorded in 2008, village Georgievka, Ukraine).

In contrast with rituals during the labor of a child, influenced a lot by medicine applied out of home, the sacred "knowledge" about rituals before and after the birth is more survival to external changes because such rituals are left under home and family control. The need to follow traditional practices is explained by the elderly informants in terms of inevitable consequences for women and children if traditions are ignored. It is considered, for example, that till 5-6 months after birth, a baby must be tightly swaddled with a specially knitted cord (Albanian $p o j$ ) to have child's legs slender. However, nowadays young mothers no longer hold to the tradition of swaddling. And that become a subject for "grandmothers" more often to look back to the practice: "To have child's legs slender, we swaddled with "poj". When took it off, there were strips all over the body. Now nobody swaddles now and the legs of all children are crooked" (S.M. Shopova, born in 1938, Albanian, recorded in 2010, village Devninskoye, Ukraine).

Practices accompanying traditional quarantine after giving birth provoke the most negative reaction, for example, in a situation when a young mother immediately goes out for a walk with a baby stroller. According to beliefs, a woman remains "unclean" for forty days after childbirth and presents an accessible object for the evil eye. At the same time, a new mother herself is a source of danger for people around. The instability of the newborn and the mother and their simultaneous presence in the real and the other worlds dictate the following the various ritual and everyday restrictions (Tsivyan, 1990, 179-184; Bajburin, 1993, 41): a woman is forbidden to go out of the home yard, to do farming, to prepare food, to take water from a common well, etc. "Forty days it was forbidden to take a baby out. And woman after birthing didn't go out of yard - when a woman goes, the ground is burning 
around for 40 meters. Such a great sin" (E.N. Melnichuk, born in 1934, Albanian, recorded in 2011, village Georgievka, Ukraine). "One woman went out to hang the swaddling clothes up in the yard. And she was said: "Huh, just turned from the hospital and went already out!" And her leg has turned blue and she was maimed a cripple" (A.D. Cherak, born in 1931, Albanian, recorded in 2010, village Gammovka, Ukraine).

The disregard of the old Albanian traditions by young generation is treated by elder people as a loss of authentic culture. Another example relates to the norms of traditional nepotism which used to be hereditary. The "god-father" or "god-mother" were in relation to all children in one family and the status was passed to a representative of the next generation only after the death of the senior member of the god-parent's family (Ivanova, 1995, 284-285). Such nepotism, typical to the Balkan cultures, was often equated with blood kinship also causing restrictions on marriage relations between two families (Bromley, Kashuba, 1982, 199-200; Zhugra, 1998, 175). In present times the nepotism established between members of two families is changing. Today the parents are likely to choose not the only god-parent for their children but for every ones that obviously could be influenced by East Slavic tradition to find godparents for a child according to their sympathy for someone, close relations or some economic or mercantile interests (Gavrilyuk, 1981, 115-139; Bajburin, 1993, 47-48). As the informant V.A. Litvinova (born in 1933, Albanian) said, today children are baptized in "Russian style", meaning that more often god-parents are relatives, cousins or close friends of baby's parents. The ignorance of the traditional norms of Albanian nepotism is associated with the loss of the culture's identity and criticized by the older generation: "Who baptized my husband should have baptized my children. They die and then their children baptize my children. We do not have outsiders. But now... Ten children - ten god-parents" (A.I. Kanarova, born in 1939, Albanian, recorded in 2010, village Georgievka, Ukraine).

\section{Main figure in cultural memory of childbirth: a midwife}

A figure of a midwife takes a special place in the hierarchy of "bearers of knowledge". The women's memories demonstrate the high importance of the midwife and her ritual actions with a mother and a child. Home 
childbirth refers to the irretrievable cultural past, that why we have to deal with retrospective memories told by informants, representing values that formed the image of a midwife. These stories are rich in details of how the midwife was preparing for the childbirth, what things she brought along, what prayers she said, how she cut the umbilical cord, how she cared about a woman in labor, how she bathed the baby, swaddled baby and so on. A midwife was a respected person in the village, because it was believed that she "saved all women". Aged informants, who remember traditional obstetrics from their mothers, can easily number all midwifes including their names who ever lived in the village. Although there is no midwife in villages by now, the tradition to respect a midwife is still strong: women feel duty to take care about midwife's graves in the cemetery because they helped their mother to give birth.

The first maternity home, which was just a separate room in a rural house, was opened in village Georgievka in 1940 but lasted for a short time, till 1941. Then it was moved to the district center, Priazovye, and functioned as a medical home for women from all nearby settlements. According to our data, at first village women tried to avoid the official medical help and preferred to seek help from already known for them midwifes, the experienced old village woman. Despite the opportunity to have qualified medical care, in the 50s women continued to give birth at home, and only in the early 1960's of XX century the traditional midwifery gradually began to disappear. Domestic obstetrics was pursued, but despite the decrees of the Soviet government since 1922 forbidding private obstetric practice, it continued to exist secretly in rural areas in different parts of Ukraine until 1970's (Boryak, 2009, 81, 123).

It stands to reason that village midwives didn't have any medical background, but nevertheless women trusted them more than doctors. Aged informants, who caught up to that time, still believe that it was better to give birth with a midwife, because she was more concerned about the woman in labor:

I can say that at my childbirth, how many years I live, no woman died because of midwife. But due to a fault of the doctor in 1950, when our people called a doctor..., the doctor came and became so angry, that the child immediately jumped out, she immediately ripped off the placenta and she [the woman in labour] immediately died (A.K. Dzingova, born in 1924, Albanian, recorded in 2011, village Georgievka, Ukraine). 
One of the serious reasons to give birth at home, not in a hospital, was a lack of opportunity to stick to the norms of traditional medicine under the supervision of obstetricians. For example, it is considered obligatory to give a woman a joilt of vodka after the giving birth in order to warm her up and to have innards disinfected. In maternity hospitals such remedies were not applied and further all possible women's health problems were treated as consequences of "wrong" medical care: "After the giving birth we gave vodka to the mother to warm her up. But in the hospital they did not let them drink vodka. But women were healthier after vodka, still all the healthy ones that gave birth with midwifes" (S.M. Shopova, born in 1938, Albanian, recorded in 2011, village Devninskoye, Ukraine).

Conventional wisdom about the poor treatment and lots of infections in hospitals created an absolute women's distrust to official medicine. At the same time, our informants admit that midwives could not cope with abnormal births without special medical means, for example, in case of maternity fever or miscarriage of a child. However, we have never heard a word about midwife's guilt on it because of her high social status in a traditional society and folk beliefs in her necessary ritual participation in the human birth. Tragic death was treated as predestined unhappy fate, which no one could prevent. Both in real and ritual circumstances a midwife played a role of mediator between a human and the world. Due to that, the ongoing ritual scenarios organizing the life of the rural and family community were also involved in relations with a midwife: she nursed a woman after childbirth for nine days, she was engaged in her housework, participated in baptism and wedding of a child that she delivered.

This sacred connection of women and midwifes is also reflected in after-death mythology: for the funeral of the midwife, all women who gave birth with her help, bring a handkerchief that should be tied on the hand of the deceased. Women believed that in the afterlife the midwife would recognize them by the handkerchief and show them the way to the heaven.

The image of a midwife stands by woman's collective and individual duty to her. In case of death it was considered compulsory to say goodbye and all women who gave birth with her carried the coffin on their hands. Based on the idea of gratitude, the funeral tradition provided an opportunity to thank a midwife once again in case if a woman didn't gifted her in time, 
after giving birth. We recorded a narrative about situation when a woman could not thank a midwife because of extreme poverty, but then, mindful of her duty at the funeral, she put a dress and bread in the coffin of midwife.

There is an interesting fact that folk obstetrics in the South Ukraine multiethnic community was above any ethnic boundaries: equally Russian, Ukrainian, Albanian, Bulgarian or Gagauzian women became midwives and helped every family within the village. The intensive intercultural contacts in birth practices are emphasized by mutual honoring of a midwife on "the day of midwife" - Albanian a Babos dita, Gagauzian Babu günü, Russian Бабин день, Bulgarian Бабинден. The festival takes place on 21 of January when all the village women that have children held a celebration in the home of a midwife or a fellow-villagers. According to tradition a midwife was showered with gifts, she was funny dressed up, women rode her on a cart or in a sleigh through the village, ritually doused with water from a river or a well. The day of midwife was a symbol of motherhood and a subject to union all village women.

Today the tradition of women's gathering is no longer related to the honoring of a midwife, but continues to exist in village Karakurt. Bringing wine and snacks, on January 21 fellow-villagers gather in somebody's house, at a local cafe or bar, chat and sing songs. However, despite the transformation simply to a "female" day, the festival keeps its basic ritual functions. As before, only women participate in the festivities, especially those who gave birth. If an elderly woman (for example, mother, grandmother or mother-in-law of the hostess) lives in the house where the celebration is organized, she is necessarily presented with a collective gift: some piece of clothing, a shawl or a headscarf. This gesture, without a doubt, has a direct relation to the honoring of a midwife.

\section{Conclusion}

To conclude, cultural memory of birth rituals of the Albanian diaspora in Ukraine is the collective memory of women reflexively aspiring to revive experience of their mothers. This memory which is based on the high prestige of traditional rituals for the elder Albanian generation is perceived by them as a way to save and transmit their culture as well as a way to represent 
the group's identity in a multiethnic environment in the South Ukraine. Despite the long time out of native homeland, cultural memory of Albanian birth practices preserves the important plots about the folk obstetrics, traditional practices and beliefs, images of the main personages, that allow us to reconstruct the essential features of the diaspora's tradition. Eventually some traditional plots are gradually mythologized in people's narratives as seen on the case of the midwife's image. Having no practical relevance for presence, these narratives form the special knowledge for Albanian village-women about their community's identity, true ethnic culture and collective heritage. The basic ideas of birth rituals - programming of health and well-being to a child and it's socialization with family, confessional and rural community - are reflected up to now in practices during pregnancy and after-birth rituals representing the actual ritual space of the Albanian community. Among them some cultural figures expressed in memory as lexis, concept, practice or belief show how archaic universals of cultural experience could be resistant to transformation and transmitted from generation to generation.

\section{References}

Arsh, G.L. (1992). Albanskaya kul'tura pod inozemnym igom (XVI - pervaya polovina $X I X$ v.). In: Kratkaya istoriya Albanii. Ed. G.L. Arsh. Moskva: Nauka, pp. 112-137. Assman, J. (2004). Kul'turnaya pamyat'. Pis'mo, pamyat' o proshlom, i politicheskaya identichnost' $v$ vysokikh kul'turakh drevnosti. Trans. by M.M. Sokol'skaja. Moskva: Yazyki slavyanskoy kul'tury.

Bayburin, A.K. (1993). Ritual v traditsionnoy kul'ture. Strukturno-semanticheskiy analiz vostochnoslavyanskikh obryadov. Sankt-Peterburg: Nauka.

Boryak, O. (2009). Baba-povitukha v kul'turno-istorichniy traditsii ukraïntsiv: mizh profannim i sakral'nim. Kiïv: Instytut mystetstvoznavstva, fol'klorystyky ta etnolohiyi im. M.T. Ryl's'koho NAN Ukrayiny.

Bromley, Y.V., Kashuba, M.S. (1982). Brak i sem'ya u narodov Yugoslavii. Moskva: Nauka.

Bŭlgarski dialekten atlas (v chetiri toma). (1966). II. Severoiztochna Bŭlgariya. Sŭstavlen pod rŭkovodstvoto na S. Stoǐkov. Chast pŭrva. Karti. 2901. kart; Chast vtora. Statii, komentari, pokazaltsi. Sofiya: Izdatelstvo na Bŭlgarskata akademiya na naukite.

Derzhavin, N.S. (1948). Albantsy-arnauty na Priazov'ye Ukrainskoy SSR. "Sovetskaya etnografiya" n. 2, pp. 156-169.

Desnitskaya, A.V. (1968). Albanskiy yazyk i yego dialekty. Leningrad: Nauka. 
Erll, A. (2008). Cultural Memory Studies: an introduction, In: Cultural Memory Studies: An International and Interdisciplinary Handbook. Ed. by A. Erll, A. Nünning, Berlin - New York: de Gruyter, pp. 1-18.

Erll, A. (2011). Memory in culture. Trans. by S.B. Young. Houndmills - Basingstoke Hampshire - New York: Palgrave Macmillan.

Gavrilyuk, N.K. (1981). Kartografirovaniye yavleniy dukhovnoy kul'tury: Po materialam rodil'noy obryadnosti ukraintsev. Kiev: Naukova dumka.

Ivanova, Y.V., Chizhikova, L.N. (1979). Iz istorii zaseleniya yuzhnoy Ukrainy. In: Kul'turno-bytovyye protsessy na yuge Ukrainy. Ed. Y.V. Ivanova, Moskva, pp. 3-11.

Ivanova Y.V. (1995). Albantsy. In: Deti v obychayakh i obryadakh narodov zarubezhnoy Yevropy. Ed. N.N. Gratsianskaya, A.K. Kozhanovskiy. T. 1. Moskva: Nauka, pp. 262-309.

Ivanova,Y.V. (2006). Albantsy i ikh sosedi. Moskva: Nauka.

Morozova, M.S. (2012). Arkhaizmy i innovatsii v dialektnoy sisteme na primere govora albantsev Ukrainy. "Acta Linguistica Petropolitana. Trudy Instituta lingvisticheskikh issledovaniy RAN". T. VIII, chast 3. Sankt-Peterburg: Nauka, pp. 533-556.

Novik, A.A., Buchatskaya, Y.V., Ermolin, D.S., Dugushina, A.S., Morozova, M.S. (2016). «Priazovskiy otryad». Yazyk i kul'tura albantsev Ukrainy. Chast' 1. T. 1. Ed. A.A. Novik, Sankt-Peterburg: MAE RAN.

Plotnikova, A.A. (2004). Etnolingvisticheskaya geografiya Yuzhnoy Slavii. Moskva: Indrik.

Sharapova, L.V. (1990). Albanoyazychnyye poseleniya Bolgarii i Ukrainy. In: Osnovy Balkanskogo yazykoznaniya. Yazyki balkanskogo regiona. Chast 1 (novogrecheskiy, albanskiy, romanskiye yazyki). Ed. A.V. Desnitskaya, Leningrad: Nauka, pp. $114-124$.

Tsivyan, T.V. (1990). Lingvisticheskiye osnovy balkanskoy modeli mira. Moskva: Nauka.

Zhugra, A.V. (1998). Albanskiye sotsionimy i sistema terminov rodstva. In: Algebra rodstva: Rodstvo. Sistemy rodstva. Sistemy terminov rodstva. Vyp. 2. Ed. V.A. Popov. Sankt-Peterburg: MAE RAN, pp. 167-185.

\section{Archive data}

KD (QSA) - Kartoteka e dialektologjisë (Qendra e Studimeve Albanologjike), Tirana, Albania.

KD (QSA): boganik - Boganik. In: Kartoteka e dialektologjisë (Qendra e Studimeve Albanologjike).

KD (QSA): poganik - Poganik. In: Kartoteka e dialektologjisë (Qendra e Studimeve Albanologjike). 